The International Journal of Engineering and Science (IJES)

|| Volume || 6 || Issue || 5 || Pages || PP 46- 51 || 2017 ||

ISSN (e): $2319-1813 \operatorname{ISSN}(\mathrm{p}): 2319-1805$

THE IJES

\title{
Evaluation of Tax Inspection on Annual Information Income Taxes Corporation Taxpayer (Study at Tax Office Pratama Kendari)
}

\author{
Ishak Awaluddin ${ }^{1}$, Nur Isma Purnama. $\mathrm{S}^{2}$ \\ ${ }^{1,2}$ Department of Accounting, Faculty of Economics and Business Halu Oleo University, South East Sulawesi, \\ Indonesia
}

\begin{abstract}
-
This research aims to evaluate the implementation of the tax inspection against the letter of annual information corporation taxpayer which is done by the tax inspection at the tax office Pratama Kendari. This research is a qualitative descriptive. Data were collected from interview and documentation. Data analysis method used is the descriptive with how to describe the implementation of the tax examination. The research result show that the tax inspection conducted by the Tax Office Pratama Kendari is in accordance with the terms of the specified examination, namely the term of the Regulation Minister of Finance Republic Indonesia number 184/PMK,03/2015 about changes to the regulation of the Minister of Finance number 17/PMK.03.2013 about procedure for tax examination. The implementation of tax inspection on the letter of annual information corporation taxpayer on the Tax Office Pratama Kendari provide a good influence in the improving the effectiveness of the taxpayer in his tax obligation.
\end{abstract}

Keywords: Tax Inspection, Letter of Annual Information, Corporation Taxpayer.

Date of Submission: 04 May 2017

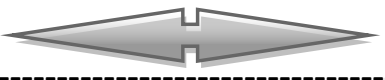

Date of Accepted: 17 May 2017

\section{INTRODUCTION}

Tax is the greatest potential for the state to finance the development i.e $75 \%$ of APBN donated from the tax sector, therefore the government more optimize the role of the tax sector to increase tax revenue. Tax revenues still need to be improved considering that the potential for tax revenues has not been maximized. Therefore, in line with the development and economic growth is increasing, so it should be realized that many tax problems are no longer in accordance with existing conditions, thus demanding a refinement of tax laws, so that state revenues sourced from the tax sector can be maximized. Government efforts to increase domestic revenues from the tax sector, among others by changing the tax collection system of the official assessment system into a selfassessment system, in which the taxpayer is authorized to determine for himself the amount of tax payable by calculating, depositing and reporting his own tax payable by conveying letter of notification. While the fiscal party is believed to supervise in accordance with applicable law, caused by regulations that require taxpayers to apply the self-assessment system resulted in not a few taxpayers who take action active resistance against taxes. Active resistance includes tax avoidance, tax evasion, and tax delinquency. The amount of tax payable is calculated by the taxpayer itself and reported through the Annual Tax Return (SPT). Upon submission of Annual Tax Returns reported by the Taxpayer is followed up by each Tax Office located in every region in Indonesia, and one of them is the Tax Office Pratama Kendari.

Notification Letter is a letter used by a taxpayer to report the calculation and / or payment of tax, tax object and non taxable object, and / or property and liability in accordance with the provisions of the taxation legislation (Siti Resmi, 2011: 19). The function of the notice is to oversee the tax revenue. Therefore, taxpayers' compliance in SPT reporting should be increased so that the supervision of tax revenue becomes effective. Taxpayer Compliance in SPT reporting can be seen from whether SPT has been reported by Taxpayer or not, SPT filing must be true, clear, and equipped with its attachments and must be reported in accordance with the time limit specified.

There are still many taxpayers who do avoid the obligation of taxation that is not reporting Annual Income Taxes Agency. This can be seen from the total amount of SPT reported by the corporate taxpayer of Tax Office Pratama Kendari from 2012 until 2015 which shows the effectiveness level of the corporate taxpayer in fulfilling the tax obligation to report the annual tax return is still very low. Consequently, the tax authorities in this case the Directorate General of Taxes are authorized by law to conduct the examination. Tax inspection is expected to increase the level of taxpayer's effectiveness of the agency in reporting its annual income taxes which will ultimately have an impact on state revenues. 
Based on the above background, the formulation of this research problem is whether the Tax Inspection onAnnual Income Taxes on the Tax Office Pratama Kendari has been implemented in accordance with the established procedure ?, The purpose of this study is to conduct an evaluation of the implementation of tax audits of the Annual Income Taxes in the Tax Office Pratama Kendari.

\section{Taxes}

\section{THEORITICAL REVIEW}

Definition of taxes according to Law no. 28 of 2007 concerning the Third Amendment to Law No. 6 of 1983 concerning General Provisions and Tax Procedures, namely "a tax is a mandatory contribution to a country owed by an individual or a coercive body under the Act, Direct and used for the purposes of the state for the greatest prosperity of the people ".

The above definition of the authors can conclude that the tax is the obligation imposed on the people against the coercive state treasury under the law, where the people do not get direct service rewards but instead used for national development and welfare of the community. The authors draw the conclusion that the characteristics of the tax may be summarized as follows: (a) Taxes levied under laws and regulations, (b) payments of taxes owed by persons or entities (taxpayers) may be imposed, (c) Tax payer can not enjoy direct contracting from the government, (d) Taxes levied by the State either through the central government or local government so that there is a term of central tax and local taxes, (e) tax revenues are used for financing expenditures, and If there is an excess then the rest is used for public investment.

\section{Tax audits}

Tax audits are generally necessary to detect fraud committed by taxpayers and also encourage them to pay taxes honestly in accordance with applicable regulations. The purpose of the examination according to the decree of the Minister of Finance Republic Indonesia number 199 / PMK.03 / 2007 is to examine compliance with the fulfillment of tax obligations in order to provide legal certainty, justice and guidance to taxpayer and other purposes in order to implement the provisions of taxation legislation.

Definition of Tax Inspection according to Mardiasmo (2009: 50): "Tax inspection is a series of activities to search, collect, process data, collect and or other information to test compliance fulfillment of tax obligations and other purposes in order to implement the provisions of tax laws".

The object of the Tax Inspection is the Taxpayer's Financial Statement which forms the basis of the Annual Income Taxes. Inspection is an activity undertaken by the Directorate General of Taxes, in this case tax inspector (tax officer) of the taxpayer for the fulfillment of tax obligations under the tax law for various purposes. Inspection action is an action performed by tax officials (tax authorities) in order to carry out examination of the taxpayer, to find materials in determining the amount of tax payable and the amount of tax payable.

The above definition of the authors can conclude that the Tax Inspection is not only to test compliance fulfillment of tax obligations but also to conduct supervision of compliance fulfillment of tax obligations.

\section{Letter of annual information}

A letter of annual information is a letter that the taxpayer uses to report the payments and / or payments of taxes, tax objects, and / or objects and / or assets and liabilities, in accordance with the tax laws and regulations. Letter of notice based on the reporting period, there are two kinds of SPT namely: (1) Letter of notice period is notice letter for a period of tax reported every month; (2) An Annual Taxes is a notice letter for a tax year or portion of a tax year reported annually. While based on the tax subject, there is SPT Individual Taxpayer and SPT Corporate Taxpayer. The SPT in accordance with the topic of discussion of this research is the annual taxes of corporate taxpayers.

The deadline for submission of SPT is provided as follows: (1) For SPT Period, must be submitted no later than 20 days after the tax period expires; (2) For the annual income taxes, must be submitted no later than 3 months after the end of the tax year. The taxpayer may apply for extension of the SPT delivery period within a period of six months. The application for extension of the SPT is submitted in writing accompanied by a statement regarding the temporary calculation of tax payable in one tax year and proof of payment of the under payment of the under payment tax. If the SPT is not submitted after the deadline or the deadline for extension of the annual SPT submission will be issued Warning Letter.

\section{Income Taxes}

Siti Resmi (2003: 74), states that the Income Taxes is the tax imposed on the subject of tax or income received or obtained within one tax year. The subject of income tax is something that has the potential to earn income and be subjected to income tax. The object of income tax is an additional economic capability received or obtained 
by the taxpayer either from within or outside the country, which is used as consumption or to increase the taxpayer wealth concerned with any name and form.

Type of Income taxes or called tax object in accordance with Article 4 paragraph (1) of the Income Taxes Law shall be grouped: (1) Any reimbursement in respect of employment or services received or obtained including salaries, wages, benefits, bonuses, pensions, or other forms of remuneration; (2) Prizes of drawings or work and awards; (3) Operating Profit; (4) The receipt of tax returns that have been charged as fees; (5) Interest, including premium, discount, and other benefits due to refund guarantee; (6) Dividends, under any name and form, including insurance companies at policyholders, and SHU Shares of Cooperatives; (7) Royalties; (8) Leases and other income related to the use of property; (9) Acceptance or receipt of periodic payments; (10) Insurance Premium.

\section{Corporate Taxpayer and Annual Income Taxes}

Taxpayer of the Taxpayer Understanding Agency as defined in the Criminal Procedure Article 1 is an individual or entity which in accordance with the provisions of taxation legislation is determined to perform taxation obligations, including certain tax collectors or tax-deductible. Entity is a group of persons and / or capital which is a unity of either business or non-business which includes limited liability company, limited partnership, StateOwned Enterprise or Region by name and in any form, Firma, Cooperative, Pension fund, Associations, Foundations, Mass organizations, Socio-political organizations or similar organizations, institutions, permanent establishments and other bodies.

Understanding of the SPT is a letter by which the taxpayer is used to report the calculation and or payment of taxes, tax objects and non- Objects of tax and or property and liability, according to the provisions of taxation legislation.Based on the reporting time period there are two kinds of SPT is the monthly SPT reported every month, and Annual Tax Returns are reported every year. While based on the tax subject is SPT taxpayers and taxpayers SPT Taxpayer Agency, The SPT in accordance with the topic of this study is the annual tax returns of corporate taxpayers.

\section{Previous Research}

Prior research relevant to this research, that is research conducted by Himayah (2005) which examines about "Implementation of Tax Inspection on Annual Taxes of Individual Taxpayer at Tax Office Pratama Jakarta" concluded that the examination the tax on the annual taxes of individual taxpayers in Tax Office Tebet Jakarta has been very effective, indicating that the taxpayer compliance to be examined is high and the examiner does not have any constraints and obstacles in carrying out the inspection so that the tax audit can complete the examination on time and In accordance with the Tax Inspection Order (SP3). Equation research Himayah (2005) with this research is equally examine the tax audit and use the same method of descriptive analysis. The difference lies in the object of research, previous research conducted at the Tax Office Pratama Tebet Jakarta while in this study conducted at the Tax Office Pratama Kendari.

\section{Thinking Framework}

Examination is the collection and evaluation of evidence of information to determine and report the suitability between the information and the predefined criteria. Tax inspection is a series of activities to collect and process data, information, and / or evidence that is executed objectively and professionally based on an inspection standard to test compliance fulfillment of taxation obligations and / or for other purposes in order to implement the provisions of the taxation legislation.

Given the attitudes of taxpayers who are increasingly doing the avoidance of tax obligations it is necessary to be examined. Tax audits conducted to improve the effectiveness of taxpayers in fulfilling its tax obligations primarily in terms of reporting annual tax returns. To achieve optimal examination results, tax audits should be conducted in accordance with tax audit procedures and guidelines that are also standard quality inspections. Inspection procedures are the stages of the examination, ranging from the preparation of inspection, the implementation of inspection, and the preparation of tax audit reports. This is an indicator in the process of tax audit so that the examination can run effectively and the purpose of inspection can be achieved. For more details. For more clearly, the framework in this study can be described as follows:

\section{Scheme 1}

\begin{tabular}{c|c|}
$\begin{array}{c}\text { Evaluation of } \\
\text { tax audit }\end{array}$ & $\begin{array}{c}\text { Annual SPT income taxes } \\
\text { corporate taxpayer }\end{array}$ \\
\hline
\end{tabular}




\section{RESEARCH METHODS}

The object of this study is the Evaluation of the Annual Taxes of the Income Taxpayer of the Tax Office Pratama Kendari, Southeast Sulawesi. The type of data used in this study is qualitative data that is, data generated from interviews with data inspector officers and other written data related to the research.

The analytical tool used in this research is descriptive analysis, that is comparing between data and information obtained from the available literature relating to the problem under study. This descriptive method is done qualitatively by describing the sentence or theoretically by classifying the data in accordance with the group. Analysis of data results from the results data, both primary and secondary data were analyzed in order to answer the research problem. Result of interview of writer to supervisor / chief examiner at Tax Office Pratama Kendari, Implementation of Tax Inspection of SPT Annual Income Taxes done through three stages, that is planning stage, implementation stage and report making stage.

The definition of operational variables are as follows: (1) Tax inspection is an activity to search, collect, process data and other information for the purposes of loading valid taxation as well as for other purposes, in order to implement the provisions of tax legislation; (2) Preparation examination shall be an activity undertaken by the auditor before collecting the file / data file, analyzing the SPT and the taxpayer's financial report, determining the problem, determining the books and documents to be borrowed, and providing the checking means; (3) Implementation examination is an activity conducted by inspectors and coverage: compulsory examination, do the assessment of the internal system, plan the inspection of space and inspection program, do checks on books, records and documents, inspection results for mandatory tax, and conducting a closing conference; (4) The making of this Report is part of the inspection process, the inspection report describes the scope of the examination and the purpose of the examination; (5) Notification Letter is a letter used by the Taxpayer for the report and. Objects and / or objects, and conditions according to the laws and regulations. (6) Income Taxes is the tax imposed on the subject of income tax received or acquired in the tax year in accordance with the provisions of the taxation legislation; (7) A corporate taxpayer is a group of persons and or capital conducting business as well as those who do not undertake a business, and is obliged to conduct bookkeeping in the manner stipulated by the KUP.

\section{Research Results}

\section{RESEARCH RESULTS AND DISCUSSIONS}

\section{A. Tax Inspection Procedures In Tax Office Pratama Kendari}

The result of the interview with the supervisor / chief executive of the tax auditor in the Tax Office Pratama Kendari, the implementation of the inspection based on Regulation of the Minister of Finance No. 184 / PMK.03 / 2015 on the amendment to Regulation of the Minister of Finance No. 17 / PMK.03 / 2013 on Tax Inspection Procedures . Tax audit is done through 3 stages of preparation, implementation, and reporting. This stage is a general procedure performed by the examiner to recognize the activities examined:

1. Stage of Preparation, after the suggestion of the waskon and received by section examination, then formed a team discussing the waskon from section examination. Once discussed, if it is feasible and eligible sent the list of nominative to Kanwil. After approval by Kanwil an audit plan is made, program audit and identity problem which will be brought and signed by Head Office. After being signed by the head of the office was issued the Tax Inspection Order (SP2). And after SP2 is issued, transferred to the taxpayer, the WP receives the attachment of the inspection notification file and the visit report. After the WP approves the functional examiner KPP Kendari officers directly to the place where the business of WP for further examination.

2. Implementation Examination, done when the WP received SP2 and approve it and then give / lend company documents to tax inspectors. The scope of examination implementation in KPP Kendari using field inspection, where the examiner officer went directly to the location of the WP business to be examined.

3. Reporting Examination, this stage is the final stage of the process of tax audit, tax audit report describes the scope of the examination and the purpose of the examination, the identity of the subject and object examination, as well as explain about the business of the taxpayer, tax obligations that must be implemented by the taxpayer . The preparation of this tax audit report shall be conducted by referring to the Examination Working Paper (KKP), the Report of Examination Result (LHP), and the Calculation Note which has been made during the inspection process and will be written in a pre-determined form by the tax auditor. After the tax audit report is made and signed by the tax audit team, the report must be immediately signed by a Head of Office along with the Note of Tax Note. Furthermore, the Tax Audit Report and the Notes of Tax Calculation shall be submitted directly to the Tax Administration section which is then made a Tax Assessment Letter (SKP).

B. Tax Inspection Against Annual Income Tax Income Taxpayer Body At Tax Office Primary Kendari 1) Tax Inspection Team receives SP2 and Notice of Field Inspection to Taxpayer. Then submit the Notice of Field Inspection to Taxpayer upon commencement of field inspection. (2) The taxpayer being examined shall lend books, records, and documents relating to business activities and the examiner will provide proof of lending / return of books, records, and documents. (3) Based on books, records, and documents, explanations from the 
taxpayer, as well as information or evidence relating to the examination that can be obtained. Tax inspection teams conduct checks by applying inspection techniques. (4) After examination it is true that there are losses incurred in 2008 and 2009 so that it can be compensated in 2010, because the compensation brick that may be filled is the amount of fiscal losses that have occurred for a maximum of 5 tax year. And the results of the examiner's calculations in accordance with the Annual Income Tax Returns Agency PT.Dharmaco Soraya Mas. (5) The results of the inspection are set forth in the Examination Working Paper and LPP concept. Field inspection results are notified in writing to the taxpayer using the Notice of Examination Result attached with the Tax Audit Finding List. A Taxpayer who approves all results of the Field Inspection shall sign the Respond of the Result of Inspection along with the Statement of Approval on the Result of Inspection and the Minutes of Approval of the Result of Inspection and shall return it to the Head of the Tax Office.

\section{Discussion}

Tax Inspection is a series of very important activities. Tax Inspection is conducted as an effort to improve taxpayer compliance in fulfilling its tax obligations and to improve taxpayer effectiveness in reporting its Annual Tax Return. The standard of inspection policy established by the Directorate General of Taxes is to conform to the applicable rules. As for the reference used in the Implementation of Tax Inspection at the Tax Office of Pratama Kendari based on the standard of inspection policy and has complied with the Regulation of the Minister of Finance of the Republic of Indonesia Number 184 / PMK.03 / 2015 regarding the amendment to Regulation of the Minister of Finance No. 17 / PMK.03 / 2013 Procedure of Inspection.

The interview result of the writer with the executing chief / supervisor of tax inspector in KPP Kendari, The Examination of Tax on the Annual Income Tax Return of the Company is done through 3 Phase of examination which can be described as follows: (1) General inspection procedure has been done in accordance with the procedure (2) Implementation of Tax Inspection on Annual Income Tax Returns The taxpayer of the Agency at KPP Pratama Kendari is slightly obstacle caused by slow response of WP when examined sometimes there is also no data at all, (4) Scope or The type of implementation used in the KPK Kendari is the scope of the field inspection, ie the examination carried out by applying inspection techniques to obtain a more complete examination results and achieve the goal of a more effective examination.

However, in general it can be seen that the examination conducted by KPP inspection officer has been in accordance with the stipulated provisions, Regulation of the Minister of Finance of the Republic of Indonesia Number 184 / PMK.03 / 2015 regarding the amendment to Regulation of the Minister of Finance No. 17 / PMK.03 / 2013 on Procedures for Inspection.

\section{CONCLUSIONS AND SUGGESTIONS}

Based on the results of research and discussion, the conclusions that can be taken are: Implementation of Tax Inspection of Annual Income Taxes on the Tax Office Pratama Kendari has met the provisions set, regulation of the Minister of Finance on the Republic Indonesia Number 184 / PMK.03 / 2015 About Changes Upon Regulation of the Minister of Finance No. 17 / PMK.03 / 2013 on tax check procedures. The type of scope of the examination conducted in the Tax Office Pratama Kendari is to use the field inspection, the inspection will provide complete examination results and can achieve more effective examination results.

Suggestions submitted by the authors are: Implementation of tax Inspection conducted by Tax OfficePratama Kendari need to be improved so that the effectiveness and benefits can be achieved and expected to have implications on the optimization of income taxes. Attempts to improve compliance, especially in the case of reporting income taxes, should be intensified, both by the tax authorities and taxpayers as a key step to encourage taxpayers to tax-conscious and tax-conscious people. Increased professionalism of tax inspectors in Tax Office Pratama Kendari need to be improved so as to provide good service to the community, and can increase the motivation of the taxpayers themselves in fulfilling their tax obligations.

\section{REFERENCES}

[1]. Agung, Mulyo. 2007. Perpajakan Indonesia, Teori dan Aplikasi. Yogyakarta: Dinamika Ilmu

[2]. Azwar, Saifuddin. 2012. Metode Penelitian. Yogyakarta: Pustaka Pelajar Offset.

[3]. Bwoga Hanantha, Yoseph Agus dan Tony Marsyahrul, "Pemeriksaan Pajak di Indonesia". PT.Grasindo, Jakarta, 2005.

[4]. Ekowati Wahyu Wulandari 2006, Pengaruh Perilaku Wajib Pajak

[5]. Himayah, Siti (2005), "Pelaksanaan Pemeriksaan Pajak atas Surat Pemberitahuan (SPT) Tahunan Pajak Penghasilan Wajib Pajak Orang Pribadi".

[6]. Mardiasmo. 2011. Perpajakan Edisi Revisi 2011. Yogyakarta: Andi.

[7]. Mardiasmo. 2009. Perpajakan Edisi Revisi 2009. Yogyakarta: Andi.

[8]. Muljono, Djoko. 2010. Hukum Pajak Konsep, Aplikasi, dan Penuntun Praktis. Yogyakarta: CV Andi Offset

[9]. Prastiwi, Ayu Ajeng. (2010), Pemeriksaan Pajak Sebagai Tindakan Pengawasan Atas Pelaksanaan Self Assessment System Dan Tingkat Kepatuhan Wajib Pajak Pada Kantor Pelayanan Pajak Pratama Pamekasan. Fakultas Ekonomi Universitas Pembangunan Nasional "Veteran) Jawa Timur

[10]. Rahayu, Siti Kurnia. 2010. Perpajakan Indonesia Konsep\&Aspek Formal. Yogyakarta: GrahaIlmu.

[11]. Rahayu, Siti Karunia dan Suhayati, Ely. 2010. Perpajakan Teori dan Teknis Perhitungan Edisi Pertama. Yogyakarta: Graha Ilmu. 
[12]. Siti Resmi, "Perpajakan: Teori dan Kasus", Edisi Pertam, Salemba Empat, Jakarta, 2003.

[13]. Suandy, Early. 2011. Hukum Pajak Edisi Kelima. Jakarta: Salemba Empat

[14]. Undang-Undang Republik IndonesiaNomor 28 Tahun 2007 Tentang Perubahan Ketiga atas Undang-undang Nomor 6 Tahun 1983 Tentang Ketentuan Umum dan Tata Cara Perpajakan Sebagaimana Telah Diubah Terakhir dengan Undang-undang Republik Indonesia Nomor 16 Tahun 2000, Tanggal 17 Juli 2007

[15]. Waluyo. 2008. Akuntansi Pajak. Jakarta: Salemba Empat 